\title{
"Well friends, let's play jazz." An Interview with Cees Hamelink.
}

\author{
Jernej Amon Prodnik*; Cees Hamelink*.
}

* Social Communication Research Centre, Faculty of Social Sciences, University of Ljubljana, Slovenia, jernej.amon-prodnik@fdv.uni-lj.si.

** Emeritus Professor of International Communication, University of Amsterdam, Netherlands.

\begin{abstract}
An interview with Cees J. Hamelink, one of the most important scholars in global communication and international political economy of communication, who was also an active participant in several political initiatives and movements in the field of media and communication, including NWICO and WSIS. We spoke about his political ideas, scholarly work and how his fascinating life-path, which took him to different parts of the world, in many ways had an impact on his intellectual development.
\end{abstract}

Keywords: Global communication, international political economy, human rights, communication politics, the right to communicate, communication flows, communication rights, World Summit on the Information Society, cultural autonomy, musicology.

Professor Cees J. Hamelink is Emeritus Professor of International Communication at the University of Amsterdam and Professor of Human Rights and Public Health at the Vrije Universiteit of Amsterdam. He is considered to be amongst the most important scholars in global communication and international political economy of communication. His erudite approach spans from a critical analysis of communication flows and transnational media industries to human rights, social psychology, public health and culture. While often anchoring his research in political economy, his ideas and influence go beyond it, as his research includes observations from several other fields of study. He published more than fifteen monographs on communication, technology and culture, including Cultural Autonomy in Global Communications (1983, Longman), Finance and Information (1983, Ablex), The Politics of World Communication (1994, Sage), World communication: disempowerment \& self-empowerment (1996, Zed Books), The Ethics of Cyberspace (2001, Sage), Media and Conflict: Escalating Evil (2011, Routledge) and Global Communication (2015, Sage).

Professor Hamelink was also an active participant in several political initiatives and movements in the field of media and communication. These include New World Information and Communication Order [NWICO] and World Summit on the Information Society [WSIS]. He was one of the founders of the People's Communication Charter, an international initiative of different civil society associations that actively advocated for implementation of the right to communicate, which would enable voices of ordinary people to be heard. He worked as a journalist as well as a consultant on communication policy for various international organizations (especially United Nations) and governments around the world. Besides his political engagement and scholarly work, Professor Hamelink is an avid jazz musician, which translates fully into his improvised lectures and discussions. 
We spoke at the annual IAMCR conference in Leicester, United Kingdom, which took place between $27^{\text {th }}$ and $31^{\text {st }}$ of July 2016. Professor Hamelink was, amongst others, also a president of this renowned association of media and communication and is now an IAMCR Honorary President.

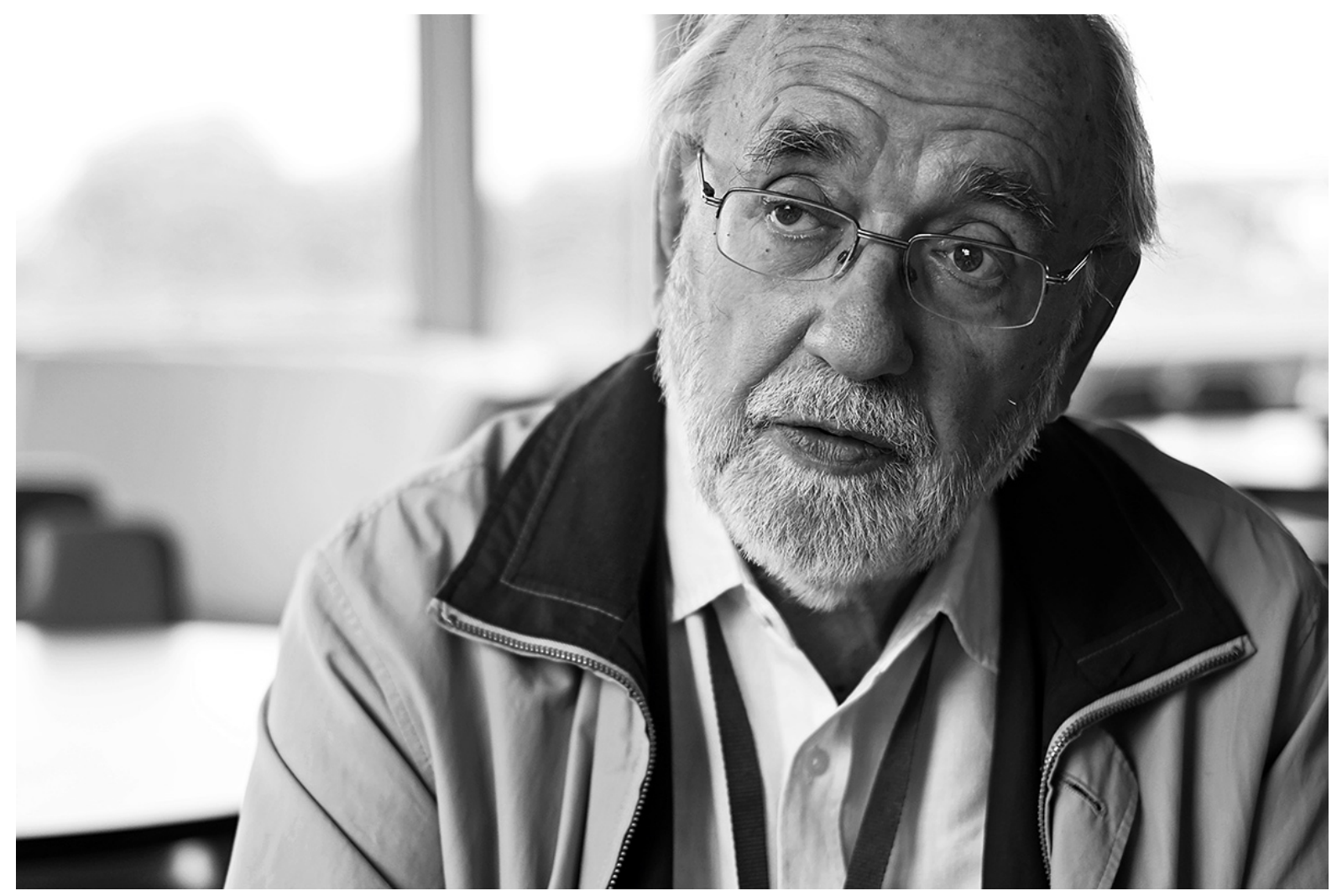

(Photo: Jernej Amon Prodnik)

Jernej: Let's start with your personal history. What drew you to media and communication, which was still very much an emerging research field at the time you entered it?

Cees: Yes, and it was not a specific field, like it is today. Some people even call it a discipline, which I think is a mistake, it is just a field of studies. But there are now communication departments. When I began there were of course no communication departments, they were always part of larger departments like sociology or political sciences. So I never studied communication, I never did media studies. I studied theology and philosophy in the early 1960s, combined with musicology, because I was a jazz player when I was young and I wanted to know more about music. As I was doing that for five years, I suddenly saw an advertisement in a newspaper that said 'We are looking for a broadcaster'. Broadcaster with the Churches broadcasting corporation in the Netherlands, which I liked, because that was one of the most radical and critical broadcasting companies. They were also someone who would do radio and television, which seemed to be interesting. There was cooperation with other left wing radical broadcast companies at that time, so this all looked very promising.

At the same time as I applied and got that job, I decided to finish my studies in theology, and then I actually became more interested not so much in what people believed or the content of that belief, but why they believe. I decided that I could probably combine working for broadcasting with studying psychology, so I entered a 
course on psychology at one of our universities, studying particularly clinical psychology, psychotherapy and psychology of religion, which was a good combination with working for a religious broadcasting company.

Those five, six years and the practice of journalism taught me a lot about media. You need to understand that at that time there was neither an academic education in communication or journalism and there were also no schools of journalism yet, which exist nowadays. So you could not train to be a journalist, you just learned it on the job. I still think that was a practical school, you were just thrown into the deep and they said: 'Make a radio programme'.

Jernej: When was this?

Cees: That was in 1965.

Jernej: So it was fairly late when journalism departments started in the Netherlands?

Cees: Yes, they only started in the 1970s.

Jernej: That's interesting, even in Slovenia (then part of socialist Yugoslavia), they were founded earlier.

Cees: Even then there was a lot of resistance amongst the editors of newspapers and editors of broadcasting companies to hire young people who were trained for the journalistic vocation, because there was a general belief that the best journalists were those who failed in academia, who studied political sciences and never made it [both laugh]. They made wonderful journalists.

Anyway, I learned a lot in those years, because I also became a foreign correspondent. I worked as a stringer for Associated Press in the Middle East for a little while, I worked in Africa, where I was teaching journalism both in Nairobi and in Addis Ababa... Then the questions began, because I thought: 'Well, there seems to be a sort of an idea that journalism was universal, that it can be practiced everywhere in the world in the same way'. I discovered quite quickly being in Africa that was not the case at all. We needed different journalistic standards in different cultures.

At that time I also began to increasingly wonder how well informed people really are. If you listen to a broadcast news programme, how much do you really know and understand about the world. I came to the following conclusion: 'Very, very little'. Because of the pressures of the job - for example you give a two minute account of what happens in the Middle East - it has to be by necessity biased and it has to be distorted. I also began to wonder about the relationship between news and propaganda and I thought that much news was really in effect propaganda for certain ideological positions. As a psychologist, I also began to be intrigued by all the lying and the deception that goes on in the newscasting.

So that was when I was completely open to the invitation from Geneva by The Lutheran World Federation and The World Council of Churches to set up a communication research desk. I applied, I got the job, and I was very happy to move into the international field and into the field of reflection on communication, and more precisely - that is what they wanted in Geneva - to explore the possibility of setting up alternative outlets for media. In the early 1970 s, alternative media was the real keyword. 
Jernej: How was that financed? It seems fairly unusual by today's standards that someone would be so open about trying to do something with alternative media.

Cees: Well the churches funded that. At that time there was still a lot of money available for such projects. There were - as they say in development cooperation - the usual suspects: the Dutch, and if the Dutch fund something then the Swedes come along, and then the Norwegians come along. So the Dutch development aid, SIDA [Swedish International Development Cooperation Agency] in Sweden, NORAD [Norwegian Agency for Development Cooperation] in Norway, FINNIDA [Finnish International Development Agency] in Finland. At that time people were really intrigued by this notion of setting up alternatives to the dominant form of journalism.

Through that I began to be involved with IPS, the Inter Press Service, which was and still is to some extent, although it is now in deep financial trouble - the real alternative press agency. You know, coming from Latin America, building its headquarters in Rome. Within IPS we really found a marvellous agency, because - at that time we had to write for AP [Associated Press], TASS [Telegraph Agency of the Soviet Union] - it became the fourth world leading news agency, with a totally different perspective on how to do things.

IPS was different, because within it different actors were present, like ordinary people or just women, who hardly played any role in dominant newsflows. That was new. What was also new at IPS was looking at the historical background of conflicts. When IPS was covering a conflict, it was not just about the conflict and about the fight. It was also about how to understand it. Good stories, investigative reporting... So it was a very interesting time and I did that for almost six years.

I also began to be more academically interested in communications, so I began to write books about the corporate structure of the media, how corporations really ruled the media. I wrote the study about finance and information, how the bankers had a great deal of interest and investment in communications. And I wrote a book on cultural autonomy, which to my pleasure is still being used. ${ }^{1}$ I hear people in conferences say 'Oh that book changed my life!', which is wonderful to hear. Because that book - thinking about cultural autonomy in global communication - basically pleaded for what I called at the time 'cultural dissociation'. I said, 'As long as developing countries remain within the remit of the developed countries, there will never be development, there will be envelopment. You will become a part of the system which is not in your interest. So dissociate yourself from that system.'

I actually learned that in psychology, because I learned that in marriages, when things go wrong, the weaker party will always suffer more than the strong party. And the weaker party in many traditional marriages of course was the woman. If they continue to communicate, it is to the detriment of the weaker party. So I thought, 'Well, that is the same. This insight from psychology can also be brought to countries. When weaker and strong countries communicate, the weaker party will always lose out, because the strong party has a bigger mouth, it has a loud voice. So dissociate yourself.'

That was a very interesting time. In 1976 I then left Geneva - l've been in all these debates, the MacBride debate and The New World Information and Communication

${ }^{1}$ See: Hamelink, Cees. 1983. Cultural Autonomy in Global Communications. Planning National Information Policy. Longman: New York. In the book, Hamelink for example emphasises that "dissociation means the conscious choice against the delusory offer of integration in an international order which appears to respond to all the interests of the developing countries, but which, in fact, represents almost exclusively the interests of the powerful." (Ibid., 97) 
Order [NWICO] and so on and so forth - you could clearly see two different streams of thinking about communication. You had the school that said 'No, we need to do things totally different, we need to build a new order, we need to go for alternatives, we need to go for cultural autonomy'. And of course you had the beginnings of neoliberalism. People who really believed that the best way to communicate was to use the techniques...

Jernej: Of the free flow of information ideology?

Cees: Yes, but free flow in the sense of being controlled by markets.

Jernej: Of course, in essence the free market ideology.

Cees: Precisely, that was the other side of the coin. I was asked at that time to forget about all these alternative projects - couldn't I do a project that was based on the 'Coca-Cola philosophy'? I remember someone saying: 'But you know, if the things that we want to do - both the ideals of the United Nations and the ideas that the churches have - if we want to make them successful, then if Coca-Cola can be successful behind the Iron Curtain and sell its bottles, we should also be able to sell our messages. So we want more marketing kind of communication.' And then I said: 'No.' And then my bosses said: 'What if we double your salary and make it tax free? And get you a blue diplomatic passport so you can travel around the world.' That was a good challenge. I'm still happy until this day that I said 'No'. So I lost my very good job in Geneva, my very beautiful place in Swiss mountains, and went back to Amsterdam.

I had a very good fortune that I was called the next day by the Dutch Ministry for Development Cooperation, by the then minister, who said: 'Cees, we need you, because we have a big project in Latin America. We have a cooperation with ILET which is the Instituto Latinoamericano de Estudios Transnacionales, the Latin American Institute for Transnational Studies - and we want you to join them.' So that was very good news because I could then expand my research agenda into issues like trans-border data flows and corporate control. I spent a little more than three years in Mexico City working with that institute, which was an interesting experience, because the institute worked very closely together with the Non-Aligned countries. We occasionally had visits at the institute from Raúl Castro, who was then the Minister of Information [in Cuba], to talk about the resolutions in the United Nations.

Why was it such an exciting time? They were all Latin Americans, mainly refugees from Latin American countries, who were hosted by the Mexican government at the time. So we had a lot of Chilean refugees that belonged to the [Salvador] Allende party during the early 1970 s, who then had to leave the country.

Good people like Juan Somavía, who was later the director of ILO [International Labour Organization], Fernando Reyes Matta, Rafael Roncagliolo, so famous names in the Latin American scene. That was really interesting, so my first question when I came there was: 'What is my role as a Dutch person?' And they said: 'Well, we'll study things in Latin America, don't you worry about that. But you are a part of the world, where the real perpetrators of big crimes come from. You are a part of that scene, so you have to study the role of the banks, the role of transnational corporations and how they affect us and what policies could be developed in order to change that.' 
I was very much at the centre of all the debates about the New International Economic Order [NIEO] and the New International Information Order [NIIO], working on the solutions for the Non-Aligned countries. What I always keep telling students is that the glamorous years were of course the 1960s, when there were student revolutions and the workers revolutions, when you had Berkeley, when you had Paris and all these places. But really, the more important years were the 1970s. They look more boring, because there is not the excitement and the commotion of the 1960s, but the really important years in my notebook are the $1970 \mathrm{~s}$, because there was a very serious attempt to make the ideals of the 1960 s a reality.

Jernej: To change the social context?

Cees: To transform societies. The only drawback in retrospective analysis - but you didn't feel that at the time - was that we just overestimated...

Jernej: What is in fact possible to do?

Cees: Yes, it was a very utopian vision, based on a very simple reasoning, which was: the United Nations is the key actor in transforming the world, but the good thing in the United Nations is that it is based on the principle 'One state - one vote'. And the states that want to change things are in the majority. So I remember sitting and working on resolutions with a team of people, with sincere belief that if the next day the United Nations General Assembly would vote, and it would vote in majority that the world economy had to be governed in a different way and that the world communications had to find a new pattern, that would indeed happen.

Jernej: I guess in that sense it was simple mathematics basically?

Cees: Yes, simple mathematics, but also - yes, that's true - but in addition, a firm belief in the power of international law and a belief in the United Nations. The first thing practically all the decolonised states did was to set up an office in New York. They wanted to be close to the United Nations. And the whole notion that we had international law, it was almost like a mantra. You only had to say 'international law'... So that was very much the feeling and the sentiment of the 1970s. I am very happy to have been at the heart of that, being in the UN meetings, being in UNESCO meetings, being in the Non-Aligned meetings, having lived through that.

Then we all of course experienced the disappointment of the 1980s. So we had the revolution in the 1960s, we had the transformation of things - or at least an attempt to transform things - in the 1970s, and then you go to [Ronald] Regan and [Margaret] Thatcher and neo-liberalism in the 1980s. It all breaks down. The United States leave UNESCO, no one wants to talk again about NWICO, that's all taboo and things change rapidly.

At that time, in the 1980s, I was asked by the then rector of the Institute of Social Studies, which is an institute for development studies in The Hague, whether I would accept a job there as an Associate Professor for international relations and international communication and come back to the Netherlands, which I did. And that was a good time, because I got the opportunity to meet a lot of students from developing countries and set up a project with UNESCO on communication policy and planning in Africa. So for many years, we did workshops with future ministers of information 
and communication in Africa. It also gave me the opportunity to publish more and to write more books.

Then in 1983 the University of Amsterdam said: 'We would like you to become our Professor of global or international communication', in a sort of a combination between the communication department, which in the meantime had been established - just a normal communication department that was growing very rapidly and is now one of the largest such departments in Western Europe, with a lot of research programmes and a lot of students - and my Chair was sort of established between the communication department and international relations and political science. So my mandate was to look at how global communication plays a role in international, political, economic and cultural relations.

Jernej: It is fascinating to hear the eclecticism of the many different strands, fields, traditions and also disciplines you started from, with finally ending in international media and communication. It is interesting also because media and communication is often very nationally based, in that sense it is very closed, but even in this sense you went wider, as you focused on the international arena. You had, so to say, a very generalistic perspective.

Cees: The reason is also because I lived abroad. I lived in the Middle East, in Africa, I travelled a lot...

Jernej: This probably contributed the most to your opinion that you cannot look at these things nationally?

Cees: I can't, because I don't feel like that. I'm a Dutch citizen, but I don't feel like it. I always tell my students: 'You want to be cosmopolitan, but you can't really be cosmopolitan, because no one lives in the cosmos.' [both laugh] I think locality is important and for me locality is very important, but not in the sense of the Netherlands, of the Dutch state, but in the sense of Amsterdam. It is like many New Yorkers say: 'We're not Americans, but we are New Yorkers'. I don't feel like a Dutch citizen, but I feel like a citizen of one of the most fascinating cities in the world that is a sort of an amalgam of around twenty different ethnic identities that live in the city. That is why I feel at home. So that makes it easier.

All these years I always had one suitcase ready for travel. Whenever I was called by the UN, or by the World Council of Churches, or by the UNESCO or by whatever other institution, saying 'Could you come, because we need a policy advisor on communication policies in Malaysia, or in Thailand, or in Mozambique...' my suitcase was always ready, so I could go. And I always felt very happy about it, because then I would encounter new challenges and meet new people, I would learn more about different cultural conceptions on communication.

Throughout all of this, of course, I have always played music. So I began to discover that in all these different situations, whether you were in Somalia, whether you were in India, whether you were in Ouagadougou, the common factor, the common ground, was always music. I could always say: 'Well friends, let's play jazz. Maybe we don't understand each other linguistically...'

Jernej: ... But through music you can. 
Cees: Through music you can. There may be all kinds of different ideas and backgrounds that we come from. Our religious conceptions or moral ideas. But l've always found it tremendously important to first find common ground, to like each other. Whenever I was on peace missions in Africa, I always thought my role is to be liked by both parties. Going to a conflict area, it is important that both parties at the end of the day, sitting at the negotiations table, go home and tell their husbands or their wives: 'Hey, he is a nice guy, this Dutch man. We like him, we trust him.'

So you always have to first establish common ground, and not necessarily in a rational way, but in the way of what I like to call "conviviality". People liking each other, wanting to cooperate. Of course playing music is a marvellous instrument to achieve that and then see what the problem is really all about.

Of course for many years I taught at the University of Amsterdam in the communication department, all these courses in global communication, but also at the restriction that I said: 'Don't ask me for administration, because I am a traveller in the department. I want to be free to go on missions, to speak everywhere in the world.'

Interestingly enough, in all those years, there was a new dimension that became more important to me: the dimension of human rights. That was not such a new thing, because l've been dealing with those issues from theology and philosophy. But increasingly in the 1990s that issue became more and more important. So when there were discussions around the world in the preparation for The World Summit on the Information Society (WSIS), I became heavily involved in the notion of communication rights and the right to communicate. For me that seemed to be a very natural thing: combining human rights issues with communication issues. That did lead to a new angle.

I also got very much involved in the CRIS movement, The Communication Rights in the Information Society. We became involved in the WSIS as one of the advisors, trying to get human rights on the agenda, which was basically a failure. Most of the member states of the United Nations had no interest for human rights dimensions in communication. And then of course I began to write about those issues. The interesting thing was that when I retired from the University of Amsterdam in 2005 - when I reached the age of 65 and there is a mandatory retirement - first of all they said: 'Hang on, keep teaching,' which I liked. But what was also interesting was that at the other university, the Free University of Amsterdam [Vrije Universiteit Amsterdam], the medical faculty said: 'We need someone to teach human rights and public health.' And I said: 'Well I know a lot about human rights by now. I can claim to be some sort of a specialist in that, but I know very little about health.' And then the doctor said: 'Oh well, that's easy [both laugh], we can teach you that in a couple of weeks, that's not a problem.' So I accepted that offer and they also said: 'We don't do age discrimination, we want to have you as a professor in our department. Not a retired professor, but a real professor.' So I got a new chair at the Free University to deal with human rights and global health issues. Again different fields.

Jernej: You really touched every field possible...

Cees: Yes, and I always liked that and I still do. If there's a new field opening tomorrow and they would say 'Hey, would you be interested?', I'd probably say 'Yes'. I sometimes accept invitations for speeches about topics that I know very little about.

Jernej: So that you learn about them? 
Cees: I learn about them. My whole mission in life is to do two things: to learn myself and by learning more myself, to be better able to get students to think critically and ask the real questions. My teaching brief is to get students to ask questions. And the best student is the one who comes up to me after a lecture and says: 'Professor, I liked it, but I think it's a lot of bullshit.' [both laugh] Those inevitably get the highest grade.

Jernej: But I presume they have to give you arguments why that is the case?

Cees: There always have to be arguments. But I come from a family that was like this. My father was a lawyer and he always taught the children to sit around the table and debate and ask questions. Ask questions of him. He would never say: 'You have to do this, because I'm your father.' When I was ten years old, my parents taught me that they had an obligation to educate us. But they thought it was very difficult and that we were much too intelligent to be educated by them, so why didn't we educate ourselves. So I come from that tradition, educate yourself, but with parents who were always there. If you had to ask questions, you could always ask questions and you got an argued answer, not an argument from hierarchy.

Jernej: This was also [Paulo] Freire's view on education.

Cees: Of course. Freire was a shining example for me, because I met him when he was in exile. We shared a room for a long time in Geneva, in the building of the World Council of Churches. What I learned from Paulo was that at the end of every working day, when he left, he stood at the door, with his little brief case and he would look at me and he would say: 'Cees, never forget! Trust the people, trust in their capacities!'

So when I later wrote a book on transnational and world communication and when I dealt with the issue of empowerment, I tried to apply all of the things l've learned from him. And the most important thing was that the notion of empowerment is absolutely wrong. Of course, it means 'I am going to empower you', which means 'I know better.' It is still a hierarchical relationship. You need to think about empowerment in terms of self-empowerment. Trust that the people can empower themselves. But create the environment in which that is possible and that certainly means people coming from the more powerful, Western countries, taking away the obstacles.

I still hear - also in this conference - people talking about empowerment, without realising that is a very colonial concept that creates new dependencies. What we really have to do is to be very critical and reflect on what are the obstacles that we create for the people to self-empower themselves. Because, certainly coming from a tradition of colonisation as I do... I mean the Dutch have been there, you know...

Jernej: Of course, if anyone has... [both laugh]

Cees: In Indonesia and the West Indies, and even in Brazil. We have done our bit. And I'm always surprised when I hear - also again this week in this conference people talking about post-colonial studies or whatever... I always say: 'Be very careful, I know what you mean, but colonialism never went away. Post-colonialism? When did it ever stop?'

Colonialism is not only the administrative control or military control, it is more in the mindset. The minds of both the people in the former colonized territories and the 
mindsets of those who are a part of the colonial strategies need to be decolonized. That is a very tough job! It will take us generations before our minds will be decolonised. It begins of course with using the right concepts and as Paulo [Freire] said, trusting the people and allowing particularly young people to ask all the questions.

Jernej: Who would you say were the key authors that influenced your thinking - besides Freire of course - when you started and when your ideas developed?

Cees: I was asked recently on Flemish television who was the most inspirational force in my life. They were expecting that I would say Immanuel Kant or Socrates. I said it was the teacher I had in basic school, Mrs. Peterson. That didn't seem to be a great philosophical source, but it was because we lived in a small village in the south of the Netherlands and she would run the Protestant school in the Catholic environment. She had all the six groups of that basic school and there were six classes in one space. So I was sitting in the third class, in the row here, and she said 'You do your own thing,' and then she was teaching the others some different classes. She was the forming power in my life, because when I was, I think, in my fourth grade so I must have been nine or ten years old - there was a conflict between that small Protestant school and the major Roman Catholic school. The kids of the Catholic school were waiting for the protestant gals and guys to fight with them and throw stones at them. So there was a conflict and there had to be negotiations about that conflict. And Mrs. Peterson said to me: 'Cees, you do it, you go to that school and negotiate for us.' And I said: 'How do ...?' And she just answered: 'Don't, that's the wrong question. You can do it. Trust yourself.' So I negotiated at the age of ten, with the powerful Roman Catholic majority, how to come to a peace agreement. Now that has been a determining force in my life. The fact that she trusted me.

That of course comes back later with Paulo Freire's saying 'Trust in the people'. I have never believed that there were students that were a lost generation, I never believed in that. Then you addressed them in the wrong way. Everyone has enormous talents, whether they are scholarly talents, musical talents, or social skills, everyone has them. You need people in your environment that say: 'You can do it!' So I now say to the students: 'I am awfully sorry, my generation really messed up the 20th century. We made a mess of it. And now it's up to you to transform the world. And I have great confidence in the fact that you can do that.'

So the authors - to come back to your question - in my life were along the line of that kind of thinking. Many of them, even [Ivan] Illich, who is all forgotten. But if I give students today his books Medical Nemesis (1975) or Deschooling Society (1971), they say 'Oh my god, the guy wrote that in the 1970s!' I met him when I was working in Mexico. I was there at the moment when he received a letter from the Vatican that he was excommunicated as a priest. And he looked at that letter and he said: 'That's bloody bad Latin!', and he corrected the letter and sent it back! [both laugh] Those people l've always found interesting. I remember one day when young volunteers for the American Peace Corps came to be introduced to Latin American by him. And they had great expectations, he's a great philosopher, great theologian, he would tell them how to provide development aid to the Latin American countries. And he had all these young people sitting there and he said: 'I have one advice for you: Don't go!' So that was it. His readings and his talking were very inspirational for me.

On the African continent, in the context of the Algerian liberation struggles, it was [Frantz] Fanon. 
So those have been really very important and by and large also the great authors of world literature. I always told students, if you want to really understand human beings, read [Fyodor Mikhailovich] Dostoyevsky, read [Lev Nikolayevich] Tolstoy, read [William] Shakespeare. You'll probably learn more from them than you will learn from handbooks on psychology.

In the communication field, of course, when I did the textbook for Sage on global communication $^{2}$ - which I didn't want to do for a long time, because I thought writing a textbook must be the most boring thing you can ever do - so one day Mila Steele, who was then the publisher at Sage, and my assistant Julia Hoffmann, who was the most brilliant assistant I have ever had and my best PhD student, came to me and invited me for a dinner in a very posh restaurant. So I thought, 'Something is wrong here.' And they looked at me and they said: 'Cees, you are one of our dearest friends, but you make a fundamental mistake, you believe in immortality. You believe that you will never die. And we think that we have to bring you the message that you'll die at some point in time.' [both laugh] And I said: 'Well what's this all about?' And they said: 'Well, look, you've been lecturing for twenty-five years and you never made a note. You never taught from lecture notes, you never used PowerPoints as we do today, so all of that teaching will get lost when you die.'

Jernej: So this changed your mind?

Cees: That changed my mind, because I thought: 'Yes, they have a point'. I like talking from the heart, as they say. I prepare myself, sort of...

Jernej: But it is basically like a jazz improvisation?

Cees: Yes, exactly. When I did my inaugural lecture at the University in Amsterdam in 1984, the only one who understood what I was doing was the piano player with whom I play jazz. He said: 'You play jazz?'

And many of the colleagues were very upset: 'He gives a lecture for forty-five minutes and he doesn't read it? How is that possible?' Well I can't read it, because then I get totally confused. And with the PowerPoint I get straightjacketed. I don't like it. I want to communicate with students, I want to look them in the eyes and I want to interact with them. Of course it is a monologue, I know that, but a monologue can be very dialogical, you can really connect with people and address them.

So the two women convinced me, but then the funny thing was, that I had no notes. How was I going to put together twenty-five years? So Julia [Hoffmann], my assistant, was very smart. She sent messages to former students and asked them for their notes. And then the funniest thing was that one of the students said: 'Well I've got to admit that what I did, occasionally, when I made good notes of the lectures like lectures on propaganda or diplomacy, I sent them to Wikipedia.' And I said: 'Well that's a bloody shame, because now we're not going to be able to use those notes. People will accuse me of plagiarism!' I would plagiarise myself! [both laugh]

Slowly I got all those notes and I talked to a lot of people. Your memory also gets triggered off. I never kept a diary, which means that a lot of things got lost, until people talked to me and said: 'But how was that in the 1970s, the 1960s and the 1980s?'

${ }^{2}$ See: Hamelink, Cees J. 2015. Global Communication. London, Thousand Oaks, New Delhi: Sage. 
Then the memories come back. But you'll see in the textbook that for all of the chapters I have an inspirational force.

Jernej: This is what I wanted to talk to you as well, because you have radical authors there, such as Herbert Schiller, Noam Chomsky...

Cees: Yes, but they were friends, that's again the conviviality. I have known all these authors.

Jernej: So they were also personal inspiration?

Cees: Yeah, also when we disagreed. We disagreed forcefully at some issues with Manuel Castells.

Jernej: Yeah, I can imagine. [laughter]

Cees: I think he's a technological determinist and of course he doesn't like it. I remember there was an ICA [International Communication Association] meeting many years ago and both Manuel Castells and Jürgen Habermas were there. And I got into a debate where I wholeheartedly disagreed with Habermas on certain issues and I also felt he was a coward, because some of the best critiques of his work came from Latin America. And I said: 'You should go to Latin America and really get exposed to what Latin Americans think about you'. But he didn't want to.

Manuel Castells also refused to go into a debate with a colleague from Venezuela at the plenary meeting of ICA. So they are both sort of gurus, primadonnas. They're beyond question and answer sessions. I got into a discussion with them at the reception and they both got fairly angry. And then someone came to me and he said: 'Oh, Cees, I'm so pleased. You managed to piss off the two most important thinkers in our field in one reception!' [both laugh] But with most of these people we were also very good friends, like Luis Ramiro Beltran and of course Herb [Schiller], with whom I attended many conferences.

Jernej: I presume that [Armand] Mattelart was the same?

Cees: Yes, Mattelart was the same. I met him in the 1970s and we worked together on a book, which is called The Corporate Village (1977). We met again a couple of years ago in Mexico, we were addressing a big audience there together. I've always liked him very much and also his wife, Michelle Mattelart, whom I also know very well.

Those were special relations and I liked the idea, which came from the publisher. They said: 'You should also tell students, who are the people that inspired you.' So all these chapters have an inspirational force. One chapter has a very inspirational force and it's Joseph Haydn.

Jernej: Yes, I noticed that. I wasn't sure when I was reading the book whether it is the composer? And I thought to myself 'Nooo, it can't be him'. [both laugh] And then I saw the bio... 'Oh, yes, it is him!' 
Cees: It was because people were asking where l'm working, knowing that l'm a jazz aficionado. I always listen to string quartets and Haydn is the most inspirational. So I thought, why not mention the guy?

Of course there is also Marshall McLuhan, who I met only once and very briefly. I couldn't claim any kind of real friendship, but I was also inspired by his out-of-the-box thinking, which in the end is not so much out-of-the-box. And I liked that as well. Sometimes we'd like to think of ourselves as being really revolutionary and creating new models. When we look at it really critically we see that we're still in a certain framework. That also tells you how enormously difficult it is to break out of frameworks.

Yesterday, I was present as a commentator in a meeting on an international panel on social progress, and I said: 'All these things that you're saying, they look new, but they're all rehashing of the old wine.' We see it is often deja-vu.

Jernej: It's also often continuity and discontinuity at the same time.

Cees: Yeah, but there is so much continuity. This whole program is again putting so much belief in the United Nations. They say: 'the United Nations now has a new program for transforming the world.' And I said: 'Wouldn't it be kind if the United Nations started transforming itself?' There is no critical debate within UN about all of its failures.

Jernej: And there were many, right?

Cees: Oh, it's such an incompetent organization, with such a lack of accountability. It's a very problematic organization. And the same is true with the communication research. We study, hopefully in a critical way, although critical research is not the dominant form of media and communication research, it has also been marginalized.

Jernej: Yes, of course.

Cees: We have great people - who are still here, fortunately - like Peter Golding and Graham Murdock. But where are junior scholars? I don't see them. Certainly not in any way as a dominant school of thinking, so critical research is in short supply in the field.

But it's even worse when you think: how critical are we about ourselves? It's nice if people study media, institutions and corporate structures in a critical way. But communication as developing discipline is also being embedded in university structures. We also need critical social study of who we are and how we are a part of university structures and how we are ruled by the requirements of fund raising and so on and so forth.

It's nice to study epistemology, theory of science, in a critical way. But we need to spend more time on thinking about our own lack of theoretical thinking, because - as I keep saying, much to the dismay, irritation and annoyance of my colleagues - I don't think that social sciences have developed any solid theoretical framework. Give me one. There's ideas, marvellous visions, there's questions... I have now just finished a new book on communication and human rights and I made the argument from a Darwinist perspective. I'm a strong believer in evolution theory and its application to the social sciences. As [Charles] Darwin himself already said at the end of his 
On the Origin of Species (1859) - I think that this might also be very useful for psychology, I think it is for evolutionary type of psychology at least.

I believe we get so many great insights, wonderful diagnoses and descriptions, but lack explanations as to why people behave and communicate in certain ways... But biology, and certainly Darwinian biology, has always been side-tracked in the social sciences. It has always been seen as a threat. Even in science as such, we don't have that many very solid theories on which you can really build on. There is maybe only one or two in physics, you got some fairly solid notions about gravitation, and in biology we've got a solid theory on the evolution of species, which gets increasing support from fossil and paleontological research, so that is a good basis to build from. That, I think, is important. I always tell the students, when they ask: 'But why are you such a Darwinist?' I say to them: 'Because I believe it helps us to understand things that we have never been able to understand by traditional social science approaches. But l'll tell you, the day that evolution theory of Darwin gets fundamentally undermined, I'll have my flag out. That's what science is all about. Science is all about contesting, disagreeing, trying to find better ways to say things.'

Jernej: But that's really going to the most ontological level of human being, starting with Darwin and then proceeding from there to social sciences?

Cees: Yeah. I like the work of a Dutch friend Frans de Waal a lot. He is one of the leading primatologist in the world and I'm always happy to read his new books. He's now written a new book Are we smart enough to understand how smart animals are? (2016). I wish that more social scientists would read books like that and begin to understand from his observations. Because mind you, the zoologists and the primatologists spend so much time observing the behaviour they want to understand.

I was just reading a study by an American primatologist who spent almost twentyfive years observing little monkeys in Indonesia. After twenty years, he says: 'I slowly began to see the patterns. I began to understand, why they do things in a certain way.' I see very few social scientists who spend that amount of time watching people communicate. It's also a part of the university structure, we do a little survey, we do a mail-questionnaire or whatever and then we publish it.

Jernej: Yes, but it's the "publish or perish" system. It's structurally limiting the critical thought as well.

Cees: Yes, that's the problem and what I appeal to, are my senior colleagues, my generation: 'Let's get away from that whole shit, let's do away with journal impact factors and all these indexes.' They have no meaning for measuring academic quality, but they are obstacles for young people to be very creative and think out-of-the-box. And they can't say it. If you are a junior scholar at the university, you should not rock the boat too early, because you'll never get a professorial post. You are judged by standards that have been cooked up usually in meetings that are attended by people who know nothing about academic quality. They become like mantras or protocols to follow.

The only ones who can be critical about it are seniors, because we have nothing to lose. They can't fire us anymore. That is a great feeling, you can say whatever you want, and no one can do anything about it. We don't have to build reputations. We don't have to build our careers. Many of us have published enough books, the world 
will be happy if we don't publish yet another one. So we can do it, but then I see a very lame response on that level as well.

Jernej: It has very much become normalised now, but if you think about it, it is complete insanity to basically bring production process similar to industrial production into academia. It has no connection to what scholarly process should be about.

Cees: Yes, and you are judged in terms of numbers.

Jernej: Of course, it all has to be boiled down to a number today.

Cees: As if you are quoted more that means something for the substantial quality of the work. Of course it doesn't, it means you are more quoted, that is the only thing it means. It has no deeper significance. Yet careers depend on this.

I would wish to call upon those of my generation to say: 'Let's stop this nonsense, let's give these juniors a real opportunity, we can trust them, we have confidence in them, many of them are very talented.' That is interesting, because we don't see it usually. Maybe we study media structures critically, but we don't see that the same thing that is happening within media is happening in academia as well. In the media by and large there are many young people who have great talents and want to become really good investigative journalists. But they can't, so we study that critically, we talk about it and we don't realize it is the same in our field. So as long as I live, I won't give up. I belong to the generation of the 1960s that doesn't give up that easily.

It's sometimes ironic to also see at a conference like this that so many things are rehashed, there's so much déjà-vu. Apparently it's so difficult to break through that. /../ Even within this institution - and IAMCR is still a very open and critical platform it's very difficult to get that. It's also because - again talking about the structures - we are victims of the conference structure. I've been trying to change that when I was president, but not very successfully. I thought we are here to really converse with each other about important scientific issues and political issues. Discussions and dialogues take place in the corridors, of course, but the major structure of the meetings is: you have five papers, which are always longer than the academics promise, because academics are just totally unreliable. 'Yes, but I read the paper, it was ten minutes.' Well, I see from the pile of papers that you're going to read from that is going to be twenty minutes. [laughter] And then there's hardly any time for response or a comment and then we go home. So there's very little real discussions. Fortunately there's a lot of informal discussions taking place and that's marvellous.

I think one of the most successful moments in IAMCR's history was in 1980 in Caracas, Venezuela. I managed to get Herb Schiller and Ithiel de Sola Pool to debate each other on the major issues of communication technology. And they were really opposing, whole heartedly disagreeing, but they respected each other. ${ }^{3}$ I had a good fortune of moderating that debate in a jam packed audience and it was so hot. We almost drifted away from the audience because of all the transpiration. And people, particularly the young people, came in and sat on the floor and listened. They were so inspired by these two. And that has never happened again. I still say to Janet [Wasko]: 'Let's try to do that once again. Have two major figures that have really dif-

${ }^{3}$ This discussion was later published in Journal of Communication. See: De Sola Pool, Ithiel and Herbert I. Schiller. 1981. Perspectives on Communications Research: An Exchange. Journal of Communication 31(3): 15-23. 
ferent positions, dialogue with each other.' Not in a shouting way, that doesn't get you anywhere, but trying to understand why they think differently, why one doesn't think the other's arguments are sufficiently solid, that kind of exchange. I think we should do that also to inspire, to say: 'This is what academia is all about'. In the end, it is about conversation in a critical way and listening to each other and building up arguments. But with the willingness to listen to arguments of someone else. It's what I call a wise discourse, we should see wisdom in communication. /../

Jernej: If I may jump back a couple of decades. Was it difficult to be a critical scholar when you started or was it more that you had international connections which made this possible? Would it be more difficult if you were just in Netherlands, especially because of the Cold war and everything that surrounded it?

Cees: Yeah, I think so. Because, remember, when I became involved in communication studies this was, of course, the time of the Cold war and of the colonial empires. Slowly countries began to be decolonized. It was marvellous to be at the IAMCR conferences forty years ago. /../ In 1974 it was in Leipzig, in the middle of the GDR [German Democratic Republic], and then in 1976 there was only 300 people from maybe forty nations, but that was when the globalization of the organization began.

Jim [Halloran] was a good president in the sense that he really stimulated internationalization and opened up the organization, also by relating it to UNESCO. As this did not happen in all academic associations, the IAMCR has always prided itself in working together. The affiliation with the UN [United Nations] made that possible. Whatever you may have against it, the UN was still a global platform, people from East and West and North and South would meet. The UN has never said: 'Oh, but you come from a communist country, so you can't participate.' That was impossible. So we very much followed the UN model.

Jernej: This was one of the few forums that was really critical at that time, right?

Cees: Very few, very few. This was the attraction for me to join the IAMCR in different positions and also to become a vice president and then the president. It was also because it did meet my needs for critical exchange and to meet critical people, such as Dallas Smythe, Herb Schiller and Kaarle Nordenstreng. People like that, who you would immediately recognize and feel empathy and sympathy with, and you would have the same critical ideas.

It was wonderful having this global aspect and meet people from really different backgrounds and cultures. I have always felt very much at home within the IAMCR. It is also because - even now that it is growing and there's almost five times as many people here [in Leicester] than there were forty years ago - it still has some of - I will use that word again - convivial ambiance, which makes it different from the International Communication Association [ICA] that is more American based. ICA is also attracting many people from different countries, but when I was asked what do I see as a difference between the ICA and the IAMCR, I said: 'Well, ICA is more like a business corporation and people deal, compete, maybe cooperate, but it's a different ambiance. IAMCR is more like a family. There are quarrels within the family, people dislike each other, as in any family, but there is this feeling of togetherness and belonging, which is quite pleasant.' I hope that for many, many years the organization will continue to expand. I'll continue to play my small role in it. I'm actually now a 
chair of the Fundraising Committee, so I'm more worried about the funds of the IAMCR.

Jernej: How important was IAMRC for NWICO, for bringing people into this debate about the New World Information and Communication Order? Were there any clear connections or do you see them elsewhere?

Cees: No, no, I think more than any other academic association the IAMCR played a role both in the MacBride Commission and discussions connected to it and in the New International Information Order [NIIO], what later was baptized NWICO, which I never really liked. I'm still the NIIO person, because that sort of relates it to the New International Economic Order [NIEO].

Jernej: And NWICO was already a step away from that?

Cees: Yes, and that was proposed by the American delegation in the UNESCO. I still remember John Reinhardt, the American ambassador, saying: 'It should be broader, it should be world, family of men, ideas and so on, and it has nothing to do with economies.' So they broke the relationship with economy and I thought that was the beginning of the end. And it was widely accepted, everyone said 'NWICO, that's what it's all about.' I think what it was all about was the proposal from the Non-Aligned countries to create both a new economic order and a new information order.

Jernej: The latter basically came out of the New International Economic Order.

Cees: Yes, and of course it made the point that information and economics are intrinsically related. If you want to have a new information order, you also need to have a new economic order. But the Americans argued: 'You can have new relations in the field of information and communication, without changing the world economy.' I never believed that was possible, and today I still feel, when people talk about new information structures, you first have to look at the broader context. What's the broader context? That has not been transformed, the UN is incapable of transforming the way in which the world economy runs.

The IAMCR was capable of providing some academic input into these debates /../ and also later with the World Summit on the Information Society [WSIS], the IAMCR did play a role in it. Not that it had much effect, but that is what we could have foreseen, because social research never had much effect on policy making. We know that some eighty percent of social research - whether it is international relations or communication - ends up in a wastebasket. Politicians are not really interested in these issues.

Jernej: It lately seems they don't even need legitimization for their actions anymore.

Cees: No. Unless you can provide an alibi, unless you can provide research that supports them. In that case, they will use it. But if it doesn't support them, why would they?

In any way, the idea that politicians benefit from well documented and wellresourced information is based on the wrong assumption. Politicians function much better in a grey area, where you can manipulate things. They're not looking for better information or for answers. We always try to provide answers to problems, but they 
know better themselves where to go and how to do it. It is all directed by interests of power or resources, material interests.

When yesterday I was in a debate about how we can write a nice chapter for a book that's going to transform the world, I said that this is still based on the assumption that anyone will listen to us.

Jernej: I think that it is an erroneous presumption that academia by itself can really change much, it's a little naïve to say the least.

Cees: We should accept the world of policy making and the world of research are totally different universes. Politicians - if they want anything - want to know that what they are doing is legitimate. And we are in the business of asking critical questions. That's not what politicians are waiting for. Politicians are always under time-pressure. Science needs patience, it is a very slow-moving process. It takes us a long time before we begin to understand things, while politicians, of course, want to know answers tomorrow. So we live in different worlds and maybe that's also good. When we try to mix those worlds, I think we are the ones who will lose out. We will necessarily be used and abused when it fits the politicians. If we get too close to them, I think that's a very dangerous route to go.

On the other hand - and that's maybe been more beneficial - the academic world has got a sort of an insight into these real issues. Yes, we were asked to be consultants to UNESCO, we wrote reports - not that it shook the world - but maybe it was more important for us. It is also because if you study in social sciences, as Jim Halloran, the deceased president of the IAMCR always used to say: 'Many social scientist study the world with the face to the bookcase and their back to the world. And that's not the way we should do it.' So he proposed turning around and looking at the real world. I think that's what happened to some of us, we were confronted with real issues.

Jernej: What you are saying probably doesn't mean that one has to be apolitical and non-normative. Quite the opposite, right?

Cees: No, no, quite the opposite.

Jernej: Also, if one reads your books, they come from certain normative presumptions.

Cees: Yes, and I think that is absolutely important. I'm always pleading that in social sciences we often fail to explain things, because we don't have sufficient theoretical backing for them. We fail to - in a useful way - predict developments. That's why we should be more normative and be more open about it. Maybe we cannot explain how societies work, but we can make a contribution on how societies should work.

I'm tremendously inspired by the definition of the World Health Organization [WHO], and mind you, this is from 1945. In its constitution they defined health as a 'complete state of physical, mental, and social well-being,' particularly the last one. That's quite something.

Jernej: That's pretty fascinating, I didn't know that. 
Cees: That's why I now say: 'If we talk about peace or whatever we talk about, let's look at that definition.' They don't say the absence of illness, they don't say the absence of war, which is peace... And I always notice, when I tell this to the students, that they look surprised. 'Complete state of physical well-being, mental well-being it's also mental illnesses and aberrations they take into account - and social wellbeing'. That's quite something. So why not set out to and try to achieve that? /../

You start from a normative perspective and say this is the norm. Now, as a social scientist, I look empirically at the real world and... Well, when I wake up in the morning, something obviously went wrong. But then, I see it as a task of the social scientist - and by implication of communications and media students - to think: 'How can we contribute to that normative goal?' Inevitably you will then have to ask very unpleasant and critical questions. Why do every day 32.000 kids die? Totally unnecessary. They have no clean drinking water, there's no hygienic conditions for them, they are far from that complete state of well-being. Did we ever communicate that to the world? Does any newspaper in the world open every day by saying that? Once you begin to see that day in and day out - it was yesterday, it will be tomorrow - and we just go about our business as usual.

Those things are very unpleasant to be confronted with. But in one of her last books about looking at the pain of others, Susan Sontag argues that you need to be confronted with them. ${ }^{4}$ For many years, as a researcher in photography and as a photographer myself, I thought the worst things of the world should not be exposed. Now I have changed my thinking. Unless we are forced to look at the pain of others, we will not take them seriously. We need to take the victims of all these processes and be reminded there are human beings and not some alien forces that do that to other human beings. Ordinary human beings do that to other ordinary human beings. And I agree with her that when we see that and are confronted with that, we may begin to wonder: 'Why can't we achieve that state of complete well-being?'

It is a long answer to your question, but yes, it's all normative. To restrict it and restrain it, as we do in many academic studies and in many academic departments and at the university - only for neo-liberal way of producing results that counts... It's a waste of our time. We should also be more careful about our time. We don't have millennia to deal with these issues, we are under the pressure of time and we are wasting enormous amounts of time. /../

Jernej: You already mentioned the question of cultural autonomy. Does your idea of dissociation still have any relevance today? Even when you proposed this idea the interconnection of the world economic system was obvious, but today it is even more intertwined through other means, for example through new communication technologies. How to think about these issues of cultural autonomy today? Do they remain in any way applicable or should we radically rethink them?

Cees: I think we need to radically rethink them, but we also should not underestimate the fact that there are still small pockets of resistance, like for example the Zapatistas in Mexico. It's very interesting, whenever I'm in Mexico, I'm always fascinated by the fact that Mayas are still there and speak their own language. And you ask them 'How is it possible that after four or five hundred years of colonialism you are still there and remain resilient?' Of course, they are again the victims of discrimination by the domi-

${ }^{4}$ See: Sontag, Susan. 2003. Regarding the Pain of Others. New York: Farrar, Straus and Giroux. 
nant Mexican class and young Mayan woman say: 'I'm so angry, because we are the original inhabitants. We have survived all these years of conquistadores and now we are again second grade citizens. We still have our own music, language, food...' I usually talk to someone who is anthropologist and writes a study on food and Mayan culture. She claims one of the reasons why they kept going was that they were always autonomous in their food production. That's also what I see in the Zapatista movement.

But it's very small pockets that will be increasingly difficult to sustain. /../ Where do you find a zone, where you could be free of all these influences, of this global envelopment? It's a global integration that we are all a part of. The question we have to ask is: How far real opposition is still possible? Because the critical social movements that are certainly there, are very successfully integrated into a world system. Or is it that we just have to hope that this system will reach its own limits at some point in time? Because you keep wondering, how long is it possible to let these 30.000 kids die every day? How long is it possible to brainwash people to such an extent that they believe that the system - which is contrary to achieving this complete state of well-being - is also in their interest?

You never fail to be surprised by the fact that in many political elections around the world people are capable of voting against their own interests. But that's understandable, of course, if you also see the media and educational structures. People are educated to believe that - in the end - the system is good for them. It's like a mental slavery.

Jernej: So it is a kind of propaganda, even though it is not really - how to put it pragmatic to talk about propaganda today? You are quickly labelled as some sort of...

Cees: But it is, also because propaganda in its original meaning - as it came from one of the Roman Catholic Popes, who actually coined the phrase propaganda - is the distribution and spreading of a belief. Propaganda fide, a wide distribution of a vision of the world.

Jernej: And we have systemic propaganda now, connected basically to consumerism and capitalism...

Cees: We do have it, of course. There is very little you can read that fundamentally contests that. When can you, in half-decent quality or critical newspapers, read a fundamental criticism of the system in which we are? And that's a part of the propaganda, 'Don't undermine the system that people believe is the best that could ever get. There is no alternative,' as Margaret Thatcher was fond of saying.

Jernej: We spoke about the inspirational authors that influenced you, how do students respond to them and how do you explain to them how to be critical? What's criticality today and how do you explain to them how to use these authors.

Cees: Well, by saying to them that I made a normative choice for these authors and that my choice is contestable, while the wonderful thing about being in a scientific environment and having the good fortune and privilege to learn at the university, is that anything that is being said by anyone is contestable. And that you have to learn to raise good questions about what I am saying, and what my good friends are say- 
ing. Don't take it for granted, but have the courage to stand up and think for yourself. Try to avoid the enormous risks of brainwashing. You'll be within a system in which people will try to enter your mind. /../ Begin contesting when you read this textbook in the course we are going to do, take it from that perspective, take nothing for granted or as ultimate truth. There is no ultimate truth, there are only different versions of the truth. Try to find your own version. /../

I always say to my students they need to be aware they'll be the ones who will always spoil the Christmas party. [both laugh] Think about it, if that's really what you want to do. Because at the Christmas party, all these people will come with all their theories - you know, about migration, or about Islamic state, terrorism, Islam - everyone has his own little theory. And you are the only one who doesn't come with a theory, but you come with this most irritating question: 'Is this the truth?' And you can really spoil a very nice party, particularly with this one uncle who always knows best. You say to him: 'Is it really true? How do you know?' That's not a question that you should ask, but it's a question that you have to ask as a responsible academic. But mind you, you'll lead a difficult life...

Jernej: As you were saying, talking about propaganda, if I am not mistaken you recently felt a need to write an open letter about [Vladimir] Putin and how he's represented in the media.

Cees: No, that's a very interesting case, because I never wrote that letter.

Jernej: No?

Cees: No, it's an interesting and instructive case about the media and especially about social media. Some people in the Netherlands wrote an open letter to Putin, claiming that the media have immediately constructed the image and the Russians are being portrayed as culprits - it was said that's the media logic, it's how the media operate - and they said: 'We don't think that's fair.'

I would have agreed with that, so in that sense I could have written the letter, if it wasn't for the bad use of English. Someone found that letter and said: 'But that can't be written by you, because the English is so bad.'

Jernej: But you were actually signed under it, right?

Cees: They referred to me in a footnote, to a lecture that I have given at the University of Netherlands - it's a television university - and l've given a lecture on why you can't believe what the newspaper tells you. That is widely quoted in the country, it is one of the most downloaded lectures ever, and they referred to that.

So someone thought, well, since they referred to the professor, he has probably written the letter. So the next version of the letter on the Internet was signed by me. And it goes from bad to worse. The next version says something like 'Dear Vladimir Putin...'

Jernej: Yes, that was a tad surprising, so I wanted to ask you about that.

Cees: No, I never wrote that letter. I could have sympathized with it, but what I find interesting is two things: First of all, this of course happens within the social media. 
Jernej: So it's very hard to check...

Cees: You can't. On some website I said: 'I didn't write this.' And the answer was immediately: 'Since he denies it, he has done it.' [both laugh] That's an interesting one, you can't win on the Internet and it's going to lead its own life.

And I thought, 'Well, this is interesting'. Because whatever criticism I may hold against traditional, professional journalism, at least in journalism there's still a sense of checks and balances and asking things. I was called by many media, I was called by a Russian media, by the leading Dutch evening newscast, who said: 'We want to have you this evening, because we've seen the letter that you have written.' But the question was immediately: 'Did you write that letter?' ...Associated Press called from New York. At least all those professionals had a sense of asking me, whether I really wrote that letter. And I explained what happened and I was no longer news.

But it's also interesting that if I had claimed - which I could have easily done - I would have been on Russia Now, the Dutch television, in Associated Press... I got hundreds of support letters, so I still became famous for something that I never did.

Jernej: The representation of Putin actually is quite propagandistic, while he's leading his own propaganda, of course...

Cees: True, in that sense I could have written it. I would have written it in my own way, with a different formulation. But I never did it and it is going to lead its own life.

What I actually found more interesting was that hundreds and hundreds of emails arrived from all over the world. Slowly the letter began to be translated to many different languages. I got a nice message from Croatia: 'All of Croatia stands behind you, you are our hero.' [both laugh] But that's interesting, what it tells us is that so many people are so fed up with the distortions and the lies in the media.

I wrote a book about it in Dutch and a part of it is now translated to English. It's called How lies govern the media? I was a year-long Dutch television commentator about lies in the media. So every week I got the opportunity to show what lies media were distributing and commented on that. And then I also wrote a book about it, which was very favourably received. But now again, with this Putin thing, I thought this is a real issue. Because those hundreds of e-mails could have easily been multiplied by many people who didn't take the trouble of sending an e-mail, and they are really angry with the fact that they are so disinformed about the world. So when someone with a certain status says this, people reckon: 'That's what I want to hear, someone who stands up and says ...they are distorting reality, they're bloody liars.'

I found that really interesting, because it sort of confirms all my ideas and makes me think again about the 1990s, when we established with a number of people the People's Communication Charter, which was a movement of critical media consumers after the Gulf War. And of course in that First Gulf War we were so misled, and the early 1990s were also the times of human rights movement, pacifist movements, women's movements... So I thought we need to have a media consumer movement. We gathered a number of people in Penang, Malaysia, with a critical Consumers Association of Penang - which is a really good political economy consumers association - and we established an international movement to be better informed and started to get people to sign this charter, which gives the rights to the media consumers. But it turned out to be very, very difficult to get people around the world to support that. It was an interesting experience. I wanted to have one million signa- 
tures, to organize an international tribunal against the pollution of our informational environment.

That ran parallel with the Cultural Environment Movement in the United States, which was run by George Gerbner, another friend from the IAMCR. We basically came to the conclusion that you have the physical environment, which is heavily polluted, and several organizations try to do something about it. But there's also a cultural environment, which is equally polluted, and we need to do something about it.

Jernej: It's also a nice metaphor.

Cees: The original idea was that the guys who destroy our cultural environment should stand trial. I had cooked up this plan to have a trial in the International Court of Justice in The Hague and we get them to stand trial. But then we need a worldwide movement and we need to have at least one million signatures and we never managed to get that many. Many people said 'Yeah, maybe it's that people don't think about the media, like fish don't think about the water in which they swim.' They take them for granted, there's nothing to really be worried about.

So that never became a great success, but the website of the charter is probably still there. The nice thing is that I got all of those notes from people and from totally unexpected places. I got this letter from a movement for critical media from a small place in India that said: 'But did you know that there's a People's Communication Charter?' Yes, I knew about it. 